\title{
Article \\ Discovery of Novel 3,4-Dihydro-2(1H)-Quinolinone Sulfonamide Derivatives as New Tubulin Polymerization Inhibitors with Anti-Cancer Activity
}

\author{
Juan $\mathrm{Ma}^{1}$ and Guo-Hua Gong ${ }^{2,3, *}$ \\ 1 Pharmaceutical Engineering College of Guangdong Food and Drug Vocational College, \\ Guangzhou 510000, China; majuan@gdyzyedu.cn \\ 2 Inner Mongolia Key Laboratory of Mongolian Medicine Pharmacology for Cardio-Cerebral Vascular System, \\ Tongliao 028000, China \\ 3 Institute of Mongolia and Western Medicinal Treatment, Affiliated Hospital of Inner Mongolia University for \\ Nationalities, Tongliao 028000, China \\ * Correspondence: gongguohua0211@163.com; Tel.: +86-0475-8214503
}

check for updates

Citation: Ma, J.; Gong, G.-H.

Discovery of Novel 3,4-Dihydro2(1H)-Quinolinone Sulfonamide Derivatives as New Tubulin

Polymerization Inhibitors with

Anti-Cancer Activity. Molecules 2022,

27, 1537. https://doi.org/10.3390/

molecules27051537

Academic Editor: Marek

M. Kowalczuk

Received: 18 October 2021

Accepted: 18 January 2022

Published: 24 February 2022

Publisher's Note: MDPI stays neutral with regard to jurisdictional claims in published maps and institutional affiliations.

Copyright: (C) 2022 by the authors. Licensee MDPI, Basel, Switzerland. This article is an open access article distributed under the terms and conditions of the Creative Commons Attribution (CC BY) license (https:// creativecommons.org/licenses/by/ $4.0 /)$.

\begin{abstract}
In this paper, a small series of novel quinoline sulfonamide derivatives was synthesized, and their structure of the target compounds were confirmed by $1 \mathrm{H}$ NMR and MS. The screening of the news target compounds' in vitro cytotoxic activities against tumor cell lines by the MTT method was performed. Among them, compound D13 (N-(4-methoxybenzyl)-2-oxo-N-(3,4,5-trimethoxyphenyl)1,2,3,4-tetrahydroquinoline-6-sulfonamide exhibited the strongest inhibitory effect on the proliferation of $\mathrm{HeLa}\left(\mathrm{IC}_{50}: 1.34 \mu \mathrm{M}\right)$, and this value correlated well with the inhibitory activities of the compound against tubulin polymerization $\left(\mathrm{IC}_{50}: 6.74 \mu \mathrm{M}\right)$. In summary, a new type of quinoline-sulfonamide derivative with tubulin polymerization inhibitory activity was discovered, and it can be used as a lead compound for further modification.
\end{abstract}

Keywords: synthesis; quinoline-sulfonamide; anti-tumor; tubulin polymerization

\section{Introduction}

The mortality rate and the incidence of cancer are increasing year by year. The number of patients who die of malignant tumors worldwide has risen to the second place among various causes of death, which seriously threatens human health [1,2]. A microtubule is one of the main components of the cytoskeleton, which exists in almost all eukaryotic cells [3], and has a variety of biological functions, such as participating in intracellular signal transduction [4], material transport and organelle transport [5], chromosome movement and regulating cell division [6]. The biggest difference between cancer and normal cells is that the proliferation of cancer cells is abnormally frequent and often uncontrolled, which makes tumor cell growth heavily dependent on the dynamic instability of tubulins/microtubules involved in polymerization and depolymerization $[7,8]$. In addition, the rapid proliferation, invasion and metastasis of tumor cells depend greatly on the supply of nutrients in the surrounding blood vessels, so blood vessel proliferation in tumor tissues is obvious. However, the endothelial cells involved in tumor angiogenesis are immature and need a skeletal network composed of microtubules to maintain their morphology $[9,10]$. Therefore, by inhibiting the polymerization of tubulin into microtubules during tumor cell division, or inhibiting the depolymerization of microtubules into microtubules, mitosis will be unable to proceed or stop, and finally induce the occurrence of apoptosis, so as to achieve the purpose of inhibiting the growth of tumor cells [11]. Since microtubules play a very critical role in the growth and development of tumor cells, they have become an ideal target for anti-tumor drug research [12].

By 2016, there were already seven active binding sites on tubulin. Among them, five binding sites are located on the $\beta$ subunit of tubulin, including the paclitaxel binding site, 
laulimalide binding site, vinblastine binding site, maytansine binding site and colchicine binding site. Meanwhile, two binding sites are located on the $\alpha$ subunit of tubulin, including the evipabulin binding site and pironetin binding site [10,13-15]. Colchicine can bind to the dimer $\beta$ subunit in the microtubule lattice and has a strong anti-tumor activity. Importantly, the polyphenol methyl ether structure in its molecule is one of the main pharmacophores that inhibits tubulin polymerization [11,16]. Combretastatin A-4 (CA-4) (Figure 1) is a natural and powerful small molecule anti-mitotic agent and vascular blocker, which is isolated from the bark of South African shrub willow [17,18]. BPROL075 (Figure 1) is an indole tubulin inhibitor and entered preclinical research as an antimitotic agent. It can strongly inhibit tubulin polymerization and has nanomolar inhibitory activity against a variety of tumor cell lines, including drug-resistant ones [19]. Interestingly, the tubulin inhibitor CA-4 and BPROL075 (Figure 1) also contain this structure [20]. In addition, the sulfonamide tubulin inhibitor ABT-751 (Figure 1), which also acts on the colchicine site, has strong proliferation inhibitory activity [19]. Moreover, there are many small molecular compounds with diverse structures, such as quinolinones that target the binding site of colchicine, which show excellent anti-tumor activity and block tumor vasculature in vivo and in vitro, showing good application prospects [21]. These interesting studies have stimulated our interest, so we envisioned putting these effective fragments together, hoping to obtain a series of tubulin inhibitors (Figure 2). Furthermore, the molecular docking and tubulin inhibitory activity of the most promising compound (D13) were investigated.<smiles>COc1cc2c(c(OC)c1OC)-c1ccc(OC)c(=O)cc1[C@@H](NC(C)=O)CC2</smiles>

Colchicine<smiles>COc1ccc(/C=C\c2cc(OC)c(OC)c(OC)c2)cc1O</smiles>

CA-4<smiles>COc1ccc2c(C(=O)c3cc(OC)c(OC)c(OC)c3)c[nH]c2c1</smiles>

BPROL 075<smiles>COc1ccc(S(=O)(=O)Nc2cccnc2Nc2ccc(O)cc2)cc1</smiles>

ABT-751

Figure 1. Microtubule inhibitors acting on the colchicine sites.

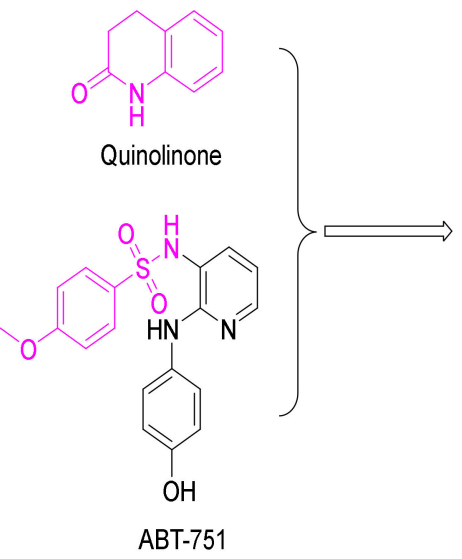

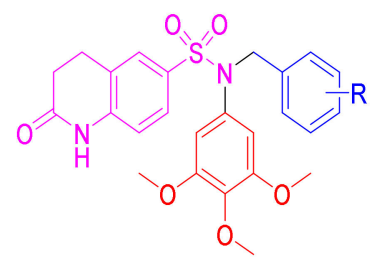

D1-D16<smiles>COc1cc2c(c(OC)c1OC)-c1ccc(OC)c(=O)cc1[C@@H](NC(C)=O)CC2</smiles>

Colchicine

Figure 2. The design strategy of the target compound.

\section{Results and Discussion}

\subsection{Chemistry}

The synthetic route for the targets is shown in Scheme 1. Both 3,4-dihydroquinolin$2(1 \mathrm{H})$-one and sulfonic chloride were chlorosulfonated to obtain intermediate A. Moreover, 3,4,5-trimethoxyaniline and different substituted aldehydes were subjected to the Schiff's 
base reaction to obtain different intermediates B [21-23]. Subsequently, intermediate B was reduced to obtain C. The target compounds D1-D16 were obtained by the nucleophilic substitution reaction between $\mathbf{A}$ and $\mathbf{C}$ [24]. Finally, all the target compounds were fully characterized by NMR and MS which was showed in the Supplementary Materials (Figures S1-S16).

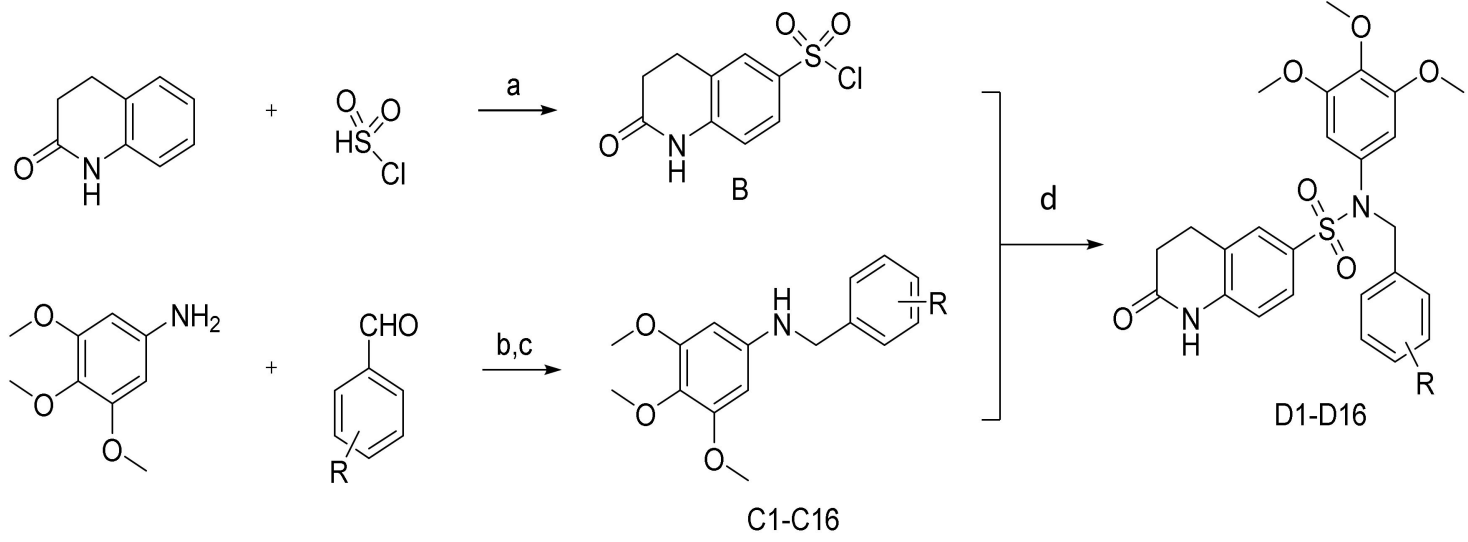

Scheme 1. Reagents and conditions: (a) $80{ }^{\circ} \mathrm{C}, 8 \mathrm{~h}$; (b) $\mathrm{MeOH}, 50^{\circ} \mathrm{C}, 6 \mathrm{~h}$; (c) $\mathrm{NaBH}_{4}, 6 \mathrm{~h}$ and (d) TEA, acetonitrile, $80^{\circ} \mathrm{C}$.

\subsection{Biological Evaluation}

\subsubsection{In Vitro Anticancer Activity}

The MTT method was used to evaluate the anti-tumor activity and cytotoxic activity of all the synthesized compounds in four tumor cell lines (HeLa, HCT-116, A549 and HepG-2) and normal liver cells (L02). At the same time, the 5-fluorouracil(5-Fu) and CA-4 were used as positive references. As shown in Table 1, most of them showed effective inhibitory activity, and $\mathrm{IC}_{50}<10 \mu \mathrm{M}$ for these four cell lines. In particular, the compound D13 showed the strongest anti-proliferative activity and was better than the positive control 5-fluorouracil. Among them, the $\mathrm{IC}_{50}$ for HeLa cells was $1.46 \mu \mathrm{M}$, the $\mathrm{IC}_{50}$ for A549 cells was $1.46 \mu \mathrm{M}$, the $\mathrm{IC}_{50}$ for HCT116 cells was $0.94 \mu \mathrm{M}$, the $\mathrm{IC}_{50}$ value for HCT116 cells was $0.94 \mu \mathrm{M}$ and the $\mathrm{IC}_{50}$ value for HepG-2 cells was $1.82 \mu \mathrm{M}$. Unfortunately, our target compound has a similar cytotoxicity to tumor cells and normal cells.

Based on the structure-activity relationship (SAR) study, we tried to prove how the substituents at different positions of the benzene ring affect its anti-cancer activity. As shown in, at the beginning, we first synthesized the ortho and meta substituted compounds, D7, D8, D9, D11 and D15. Unfortunately, they all showed poor antiproliferative activity. Then, we decided to introduce para-substituted benzaldehyde. What is exciting was that all the compounds (D1, D2, D3, D4, D5, D6 and D13) showed strong anti-proliferative activity. More importantly, in Hela and HepG-2 cells, the anti-proliferative activity of all the compounds was better than the positive control 5-Fu. Additionally, in the four cell lines, the order of the types and positions of the substituents on the benzene ring to enhance the antiproliferative activity was $4-\mathrm{OCH}_{3}>4-\mathrm{CH}_{3}>4-\mathrm{N}\left(\mathrm{CH}_{3}\right)_{2}>4-\mathrm{Br}>4-\mathrm{Cl}>4-\mathrm{F}>4-\mathrm{H}$; from this we drew the clear conclusion that the introduction of electron-donating groups at the para position of the benzene ring was more active than the electron-donating groups. In addition, the compound D13 with the 4- $\mathrm{OCH}_{3}$ substitution showed the strongest antiproliferative activity. This stimulated our interest, so we continued to introduce $-\mathrm{OCH}_{3}$ substituted at different positions to explore the effect of $-\mathrm{OCH}_{3}$ substituted at different positions on the anti-tumor activity of the compound. Unfortunately, all the compounds (D11, D12, D14 and D15) except for D16, exhibited poor antiproliferative activity. In short, we obtained a compound named D13 with good anti-tumor activity, and it was worthy of further study. 
Table 1. Antiproliferative activities of D1-D16 against human cancer cell lines ${ }^{\text {a }}$.<smiles>[R]c1ccc(CN(c2cc(OC)c(OC)c(OC)c2)S(=O)(=O)c2ccc3c(c2)CCC(=O)N3)cc1</smiles>

D1-D16

\begin{tabular}{|c|c|c|c|c|c|c|}
\hline \multirow{2}{*}{ Compd. } & \multirow{2}{*}{$\mathbf{R}$} & \multicolumn{5}{|c|}{$(\mu \mathrm{M}) \mathrm{IC}_{50} \mathrm{~b}$} \\
\hline & & HeLa & A549 & HCT116 & HepG-2 & L02 \\
\hline D1 & $-\mathrm{H}$ & $13.46 \pm 2.15$ & $14.15 \pm 1.26$ & $25.90 \pm 0.98$ & $9.87 \pm 2.49$ & $20.73 \pm 3.12$ \\
\hline D2 & $4-\mathrm{Br}$ & $3.98 \pm 0.25$ & $4.19 \pm 1.27$ & $1.95 \pm 0.77$ & $7.53 \pm 0.27$ & $10.56 \pm 1.26$ \\
\hline D3 & $4-\mathrm{F}$ & $7.54 \pm 1.48$ & $18.24 \pm 4.11$ & $3.87 \pm 0.12$ & $6.31 \pm 1.21$ & $5.31 \pm 1.08$ \\
\hline D4 & $4-\mathrm{Cl}$ & $9.67 \pm 2.1$ & $8.49 \pm 1.77$ & $4.21 \pm 0.5$ & $4.12 \pm 0.55$ & $6.35 \pm 2.03$ \\
\hline D5 & $4-\mathrm{CH}_{3}$ & $1.34 \pm 0.3$ & $2.96 \pm 0.13$ & $1.13 \pm 0.01$ & $2.36 \pm 0.11$ & $3.05 \pm 0.19$ \\
\hline D6 & $4-\mathrm{N}\left(\mathrm{CH}_{3}\right)_{2}$ & $3.63 \pm 0.98$ & $2.42 \pm 0.46$ & $2.05 \pm 0.11$ & $4.74 \pm 1.56$ & $5.31 \pm 1.02$ \\
\hline D7 & $3-\mathrm{CH}_{3}$ & $36.49 \pm 3.59$ & $34.99 \pm 6.74$ & $28.17 \pm 4.26$ & $44.31 \pm 4.31$ & $30.21 \pm 2.56$ \\
\hline D8 & $2-\mathrm{F}$ & $21.62 \pm 3.56$ & $>100$ & $17.54 \pm 1.33$ & $50.91 \pm 6.77$ & $60.21 \pm 4.21$ \\
\hline D9 & $2-\mathrm{Cl}$ & $16.94 \pm 4.11$ & $31.68 \pm 4.55$ & $12.16 \pm 2.89$ & $27.46 \pm 3.28$ & $36.25 \pm 4.21$ \\
\hline D10 & $3,4-\mathrm{Cl}$ & $75.29 \pm 10.32$ & $>100$ & $51.24 \pm 13.49$ & - & $48.26 \pm 6.64$ \\
\hline D11 & 2-Cl-5-F & $38.41 \pm 4.57$ & $19.27 \pm 2.38$ & $25.48 \pm 5.23$ & $58.37 \pm 6.93$ & $65.31 \pm 4.25$ \\
\hline D12 & $3-\mathrm{OCH}_{3}$ & $54.64 \pm 8.15$ & - & $48.23 \pm 7.46$ & $64.12 \pm 7.56$ & $56.26 \pm 2.15$ \\
\hline D13 & $4-\mathrm{OCH}_{3}$ & $1.46 \pm 0.11$ & $1.57 \pm 0.25$ & $0.94 \pm 0.31$ & $1.82 \pm 0.97$ & $3.61 \pm 1.02$ \\
\hline D14 & $3,4-\mathrm{OCH}_{3}$ & $>100$ & $49.28 \pm 12.53$ & $87.81 \pm 15.23$ & - & $66.52 \pm 7.81$ \\
\hline D15 & $2,5-\mathrm{OCH}_{3}$ & $86.36 \pm 14.23$ & - & $>100$ & $75.36 \pm 15.44$ & $>100$ \\
\hline D16 & $3,4,5-\mathrm{OCH}_{3}$ & $4.91 \pm 0.76$ & $7.34 \pm 1.44$ & $2.08 \pm 0.24$ & $5.48 \pm 1.23$ & $4.25 \pm 0.87$ \\
\hline $5-\mathrm{Fu}$ & - & $29.57 \pm 3.21$ & $8.71 \pm 0.23$ & $11.67 \pm 2.37$ & $18.31 \pm 0.76$ & $20.04 \pm 1.25$ \\
\hline CA-4 & - & $0.02 \pm 0.001$ & $0.12 \pm 0.023$ & $0.04 \pm 0.016$ & $0.05 \pm 0.021$ & $0.15 \pm 0.05$ \\
\hline
\end{tabular}

${ }^{a}$ Cell lines were treated with compounds for $48 \mathrm{~h}$. Cell viability was measured by MTT assay as described in the Section $4 .{ }^{\mathrm{b}} \mathrm{IC}_{50}$ values are indicated as the mean $\pm \mathrm{SD}$ (standard error) of at least three independent experiments.

\subsubsection{Inhibition of Tubulin Polymerization of D13}

Compound D13 showed the strongest anti-proliferative activity. Therefore, we used the tubulin polymerization detection kit to further verify its inhibitory effect on tubulin polymerization. CA-4 was used as the reference compound; in addition, the control group was also set. As shown in Figure 3, the compound D13 strongly inhibited the tubulin assembly assay with an $\mathrm{IC}_{50}$ of $6.74 \mu \mathrm{M}$. These results suggest that the compounds may inhibit the cell growth through tubulin polymerization inhibition. Unfortunately, it did not surpass CA-4 $(2.64 \mu \mathrm{M})$.
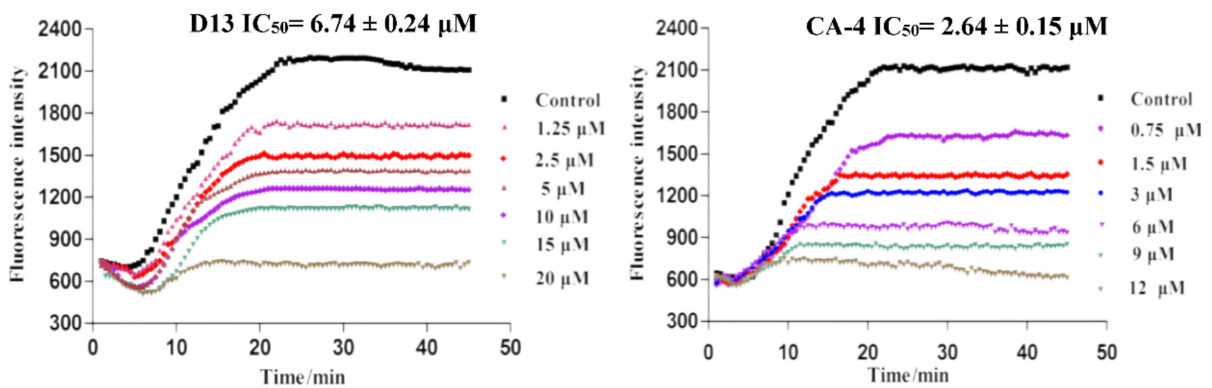

Figure 3. Compound D13, CA-4 and DMSO were incubated with tubulin in vitro, and the excitation wavelength was $360 \mathrm{~nm}$. When the emission wavelength was $420 \mathrm{~nm}$, the polymerization of microtubules within 45 min was detected.

\subsection{Docking Analysis}

We used the computer-aided drug design software Discovery Studio 2017 Server for the molecular model construction and protein structure treatment to complete the docking of the target compounds with the tubulin (Tubulin-ABT751, 3HKC. pdb). In order to study whether the binding ability of the target compound to the receptor was positively correlated with its 
anti-proliferative activity, we selected the compound D13 with the best anti-proliferative activity, D5 with less activity and D15 with the worst activity. The results are shown in Figure 4, where the compound D13 has the strongest binding ability to the tubulin receptor and shows the lowest binding energy (CDOCKER_INTERACTION_ENERGY $=-53.11 \mathrm{~kJ} / \mathrm{mol}$ ). At the same time, the binding ability of compound D5 and compound D15 decreased successively to $-37.41 \mathrm{~kJ} / \mathrm{mol}$ and $-31.5 \mathrm{~kJ} / \mathrm{mol}$, respectively. This result indirectly verifies that the target compound inhibits the proliferation of tumor cells by inhibiting the polymerization of tubulin.
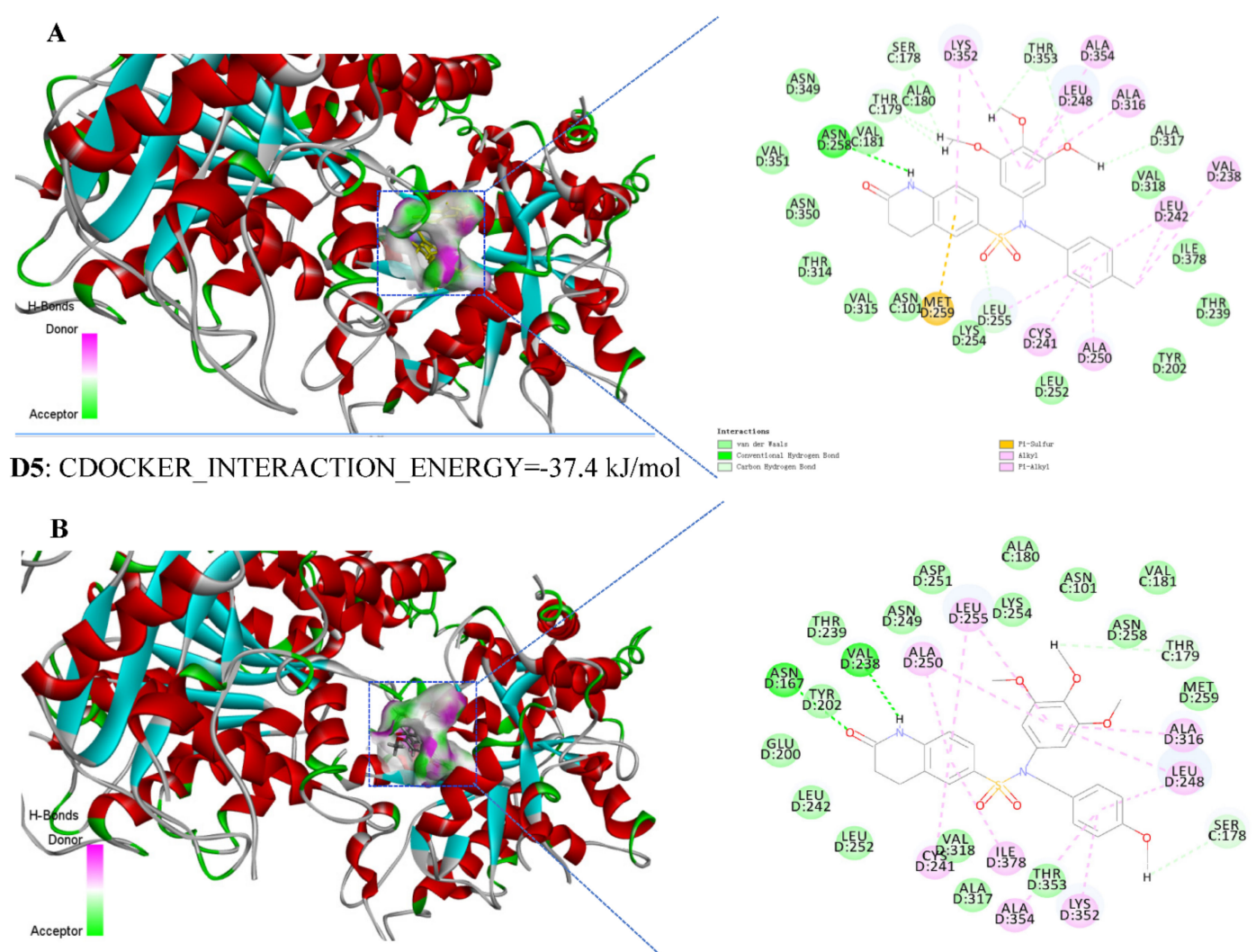

D13:CDOCKER INTERACTION ENERGY=-53.11 kJ/mo

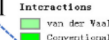
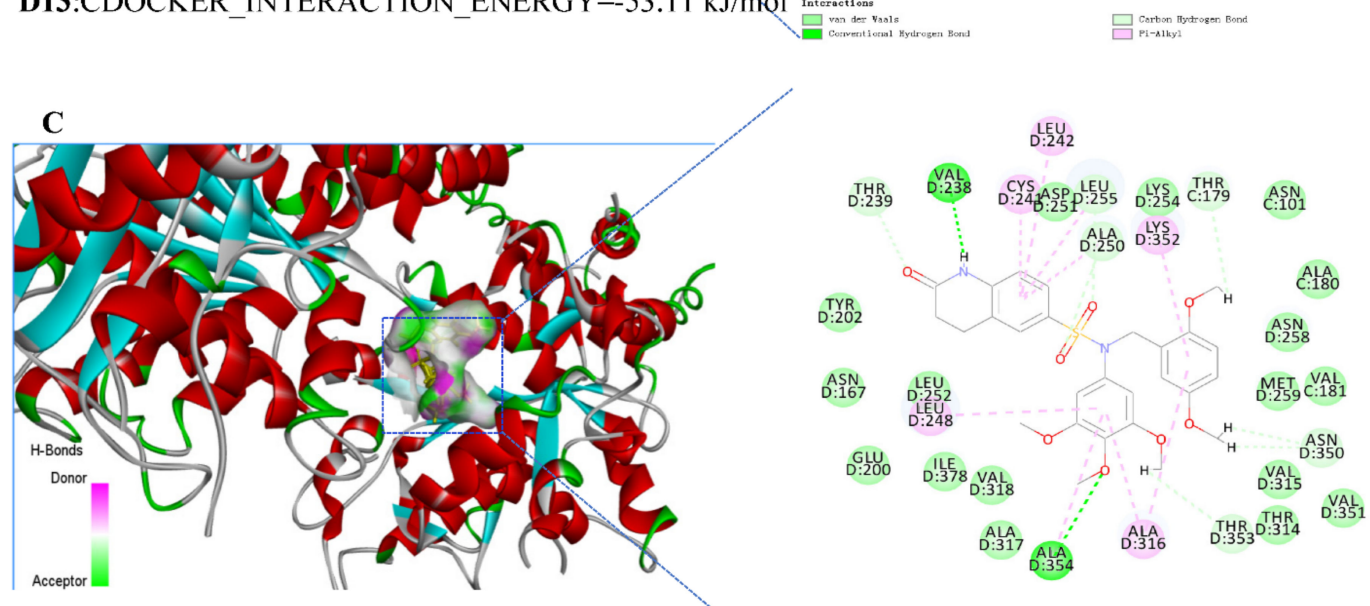

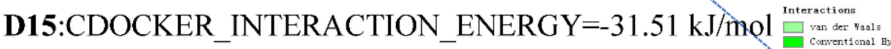

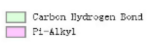

Figure 4. Docking conformation of compounds in the active site of tubulin protein (PDB: 3HKC). (A) Proposed conformation of D5 in the binding pocket of tubulin and binding energy. (B) Proposed conformation of D13 in the binding pocket of tubulin and binding energy. (C) Proposed conformation of D15 in the binding pocket of tubulin and binding energy. 


\section{Conclusions}

With the aim to further explore the novel tubulin polymerization inhibitor, a small series of novel quinoline sulfonamide derivatives was synthesized, and their antiproliferative activities with their mechanism of action were investigated. In particular, the most potent compound, D13, exhibited the best in vitro cytotoxic activity in cellular assays with a mean $\mathrm{IC}_{50}$ value of $1.34 \mu \mathrm{M}$ on the HeLa human tumor cell line, and significant potency against tubulin assembly with an $\mathrm{IC}_{50}$ value of $6.74 \mu \mathrm{M}$. Moreover, the results of the molecular docking study showed that compound D13 had a strong binding affinity to tubulin and may have played a crucial role in inhibiting its activity. In summary, a new type of quinoline-sulfonamide derivative with tubulin polymerization inhibitory activity was discovered, and the most active compound, D13, can be used as a lead compound for further modification.

\section{Experimental Section}

\subsection{Chemistry General Methods}

The raw materials used in the experiment were purchased from Aladdin reagent. The progress of the reaction was monitored by thin-layer chromatography, and a chromatographic column was used for separation. The melting point of the target product was measured in an open capillary tube (the temperature is not corrected), ${ }^{1} \mathrm{H}-\mathrm{NMR}$ was used the chemical shift of TMS as the zero point, measured by AV-300 nuclear magnetic resonance instrument, and the mass spectrum was measured with a flight mass spectrometer.

\subsection{Procedure for the Synthesis of Compound $\mathbf{B}$}

3,4-dihydroquinolin-2(1H)-one $(10 \mathrm{~g}, 68.03 \mathrm{mmol})$ was added to a $50 \mathrm{~mL}$ found-bottom flask and then stirred with $9 \mathrm{~mL}$ of sulfonic chloride (as the solvent) at $80{ }^{\circ} \mathrm{C}$ for $6-8 \mathrm{~h}$, and the reaction was monitored by TLC. After the reaction was over, we poured it into ice water and a solid precipitated out to obtain compound A. White powder; yield: $86.5 \%$; m.p. $209-212{ }^{\circ} \mathrm{C} .{ }^{1} \mathrm{H}$ NMR (300 MHz, DMSO-d 6 ,ppm) $\delta 10.15$ (s, 1H, -CONH-); 7.44 (d, 1H, $J=1.5 \mathrm{~Hz}, \mathrm{Ar}-\mathrm{H}) ; 7.41(\mathrm{~d}, 1 \mathrm{H}, J=9.0 \mathrm{~Hz}, \mathrm{Ar}-\mathrm{H}) ; 6.84(\mathrm{~d}, 1 \mathrm{H}, J=9.0 \mathrm{~Hz}, \mathrm{Ar}-\mathrm{H})$ and 2.42-3.02 (m, $4 \mathrm{H},-\mathrm{CH}_{2} \mathrm{CH}_{2}-$ ).

\subsection{General Synthesis Process of Compounds C1-C16}

3,4,5-trimethoxyaniline (500 $\mathrm{mg}, 2.73 \mathrm{mmol}$ ) and different substituted benzaldehydes (3.28 mmol) were added to a $25 \mathrm{~mL}$ found-bottom flask and then stirred with $5 \mathrm{~mL}$ of methanol (as the solvent) at $50{ }^{\circ} \mathrm{C}$ for $6-8 \mathrm{~h}$. After the end of the reaction was detected by TLC, we added $\mathrm{NaBH}_{4}(4.00 \mathrm{mmol})$ to the reaction solution and continued to react for $4 \mathrm{~h}$. The mixture was extracted 3 times with $15 \mathrm{~mL}$ of ethyl acetate and an appropriate amount of saturated brine. The organic phase was concentrated under reduced pressure and purified by silica gel chromatography to obtain compounds C1-C16. White powder; yield 65-83\%. The ${ }^{1} \mathrm{H}$ NMR of compound $\mathrm{C1}$ : (300 MHz, $\left.\mathrm{CDCl}_{3}, \mathrm{ppm}\right) \delta 7.40-7.38(\mathrm{~m}, 3 \mathrm{H}$, Ar-H), 7.35-7.28 (m, 2H, Ar-H), 5.90 (s, 2H, Ar-H), 4.32 (s, 1H, -NH), 3.81 (s, 6H, - $\left.\mathrm{COH}_{3}\right)$ and $3.78\left(\mathrm{~s}, 3 \mathrm{H},-\mathrm{COH}_{3}\right)$.

\subsection{General Synthesis Process of Compounds D1-D16}

Compound C (1 mmol) and compound B (1.1 mol) were added to a $25 \mathrm{~mL}$ foundbottom flask and then stirred with $5 \mathrm{~mL}$ of acetonitrile (as the solvent) at $80{ }^{\circ} \mathrm{C}$ for $8 \mathrm{~h}$; the mixture was extracted with ethyl acetate. The organic phase was concentrated under reduced pressure and purified by silica gel chromatography to obtain compounds D1-D16.

4.4.1. N-benzyl-2-oxo-N-(3,4,5-trimethoxyphenyl)-1,2,3,4-tetrahydroquinoline-7sulfonamide (D1)

White powder; yield 52\%; m.p. 96-98 ${ }^{\circ} \mathrm{C} .{ }^{1} \mathrm{H} \mathrm{NMR}\left(300 \mathrm{MHz}, \mathrm{CDCl}_{3}, \mathrm{ppm}\right) \delta 8.36$ (s, $1 \mathrm{H}), 7.60-7.56(\mathrm{~m}, 2 \mathrm{H}), 7.27(\mathrm{~s}, 5 \mathrm{H}), 6.88(\mathrm{~d}, \mathrm{~J}=8.2 \mathrm{~Hz}, 1 \mathrm{H}), 6.17(\mathrm{~s}, 2 \mathrm{H}), 4.70(\mathrm{~s}, 2 \mathrm{H}), 3.81$ $(\mathrm{s}, 3 \mathrm{H}), 3.66(\mathrm{~s}, 6 \mathrm{H}), 3.03(\mathrm{t}, J=7.5 \mathrm{~Hz}, 2 \mathrm{H})$ and $2.71(\mathrm{t}, J=6.7 \mathrm{~Hz}, 2 \mathrm{H}) .{ }^{13} \mathrm{C} \mathrm{NMR}(75 \mathrm{MHz}$, 
$\left.\mathrm{CDCl}_{3}, \mathrm{ppm}\right) \delta 170.88,152.74(2 \mathrm{C}), 142.30,137.56,135.96,134.54,131.75,128.49$ (2C), 128.25 (2C), 127.59, 127.41, 123.63, 115.46, 106.53 (2C), 60.65, 55.95 (2C), 55.07, 30.23 and 25.10. MS $(\mathrm{m} / \mathrm{z})$ calculated for $\mathrm{C}_{25} \mathrm{H}_{27} \mathrm{~N}_{2} \mathrm{O}_{6} \mathrm{~S}^{+}[\mathrm{M}+\mathrm{H}]^{+}: 483.16$, found: 483.18 .

4.4.2. N-(4-bromobenzyl)-2-oxo-N-(3,4,5-trimethoxyphenyl)-1,2,3,4-tetrahydroquinoline7-sulfonamide (D2)

White powder; yield 63\%; m.p. $112-114{ }^{\circ} \mathrm{C} .{ }^{1} \mathrm{H}$ NMR $\left(300 \mathrm{MHz}, \mathrm{CDCl}_{3}, \mathrm{ppm}\right) \delta 8.64$ $(\mathrm{s}, 1 \mathrm{H}), 7.57-7.53(\mathrm{~m}, 2 \mathrm{H}), 7.41(\mathrm{~d}, J=8.3 \mathrm{~Hz}, 2 \mathrm{H}), 7.15(\mathrm{~d}, J=8.3 \mathrm{~Hz}, 2 \mathrm{H}), 6.90(\mathrm{~d}, J=8.2 \mathrm{~Hz}$, $1 \mathrm{H}), 6.17(\mathrm{~s}, 2 \mathrm{H}), 4.64(\mathrm{~s}, 2 \mathrm{H}), 3.82(\mathrm{~s}, 3 \mathrm{H}), 3.68(\mathrm{~s}, 6 \mathrm{H}), 3.03(\mathrm{t}, J=7.5 \mathrm{~Hz}, 2 \mathrm{H})$ and 2.71 $(\mathrm{t}, J=7.6 \mathrm{~Hz}, 2 \mathrm{H}) .{ }^{13} \mathrm{C} \mathrm{NMR}\left(75 \mathrm{MHz}, \mathrm{CDCl}_{3}, \mathrm{ppm}\right) \delta 170.98,152.92(2 \mathrm{C}), 142.32,137.79$, $135.17,134.41,131.61,131.44$ (2C), 130.25 (2C), 127.55 (2C), 123.71, 121.60, 115.51, 106.47 (2C), $60.75,56.06(2 \mathrm{C}), 54.49,30.25$ and 25.14. MS (m/z) calculated for $\mathrm{C}_{25} \mathrm{H}_{27} \mathrm{BrN}_{2} \mathrm{O}_{6} \mathrm{~S}^{+}[\mathrm{M}+\mathrm{H}]^{+}$: 561.07, found: 561.20 .

4.4.3. N-(4-fluorobenzyl)-2-oxo-N-(3,4,5-trimethoxyphenyl)-1,2,3,4-tetrahydroquinoline6-sulfonamide (D3)

White powder; yield 51\%; m.p. $108-110{ }^{\circ} \mathrm{C} .{ }^{1} \mathrm{H}$ NMR $\left(300 \mathrm{MHz}, \mathrm{CDCl}_{3}, \mathrm{ppm}\right) \delta 8.56$ (s, 1H), $7.56(\mathrm{~d}, J=10.5 \mathrm{~Hz}, 2 \mathrm{H}), 7.23(\mathrm{dd}, J=8.5,5.4 \mathrm{~Hz}, 2 \mathrm{H}), 7.02-6.87(\mathrm{~m}, 3 \mathrm{H}), 6.15(\mathrm{~s}$, $2 \mathrm{H}), 4.66(\mathrm{~s}, 2 \mathrm{H}), 3.82(\mathrm{~s}, 3 \mathrm{H}), 3.67(\mathrm{~s}, 6 \mathrm{H}), 3.03(\mathrm{t}, J=7.6 \mathrm{~Hz}, 2 \mathrm{H})$ and $2.71(\mathrm{t}, J=7.6 \mathrm{~Hz}$, 2H). ${ }^{13} \mathrm{C}$ NMR (126 MHz, DMSO, ppm) $\delta 170.81,160.93,152.91$ (2C), 143.11, 137.46, 134.98, 133.22, 130.98, 130.76, 130.70, 127.86, 127.77, 124.66, 115.63, 115.53, 115.46, 106.99 (2C), 60.47, $56.37(2 \mathrm{C}), 53.55,30.34$ and 24.85. MS $(\mathrm{m} / z)$ calculated for $\mathrm{C}_{25} \mathrm{H}_{27} \mathrm{FN}_{2} \mathrm{O}_{6} \mathrm{~S}^{+}[\mathrm{M}+\mathrm{H}]^{+}: 501.15$, found: 501.19 .

4.4.4. N-(4-chlorobenzyl)-2-oxo-N-(3,4,5-trimethoxyphenyl)-1,2,3,4-tetrahydroquinoline6-sulfonamide (D4)

White powder; yield 61\%; m.p. $119-121^{\circ} \mathrm{C} .{ }^{1} \mathrm{H}$ NMR $\left(300 \mathrm{MHz}, \mathrm{CDCl}_{3}, \mathrm{ppm}\right) \delta 8.64$ (s, 1H), 7.58-7.53 (m, 2H), 7.28-7.17 (m, 4H), $6.90(\mathrm{~d}, J=8.2 \mathrm{~Hz}, 1 \mathrm{H}), 6.17(\mathrm{~s}, 2 \mathrm{H}), 4.66(\mathrm{~s}$, 2H), $3.82(\mathrm{~s}, 3 \mathrm{H}), 3.67(\mathrm{~s}, 6 \mathrm{H}), 3.03(\mathrm{t}, J=7.5 \mathrm{~Hz}, 2 \mathrm{H})$ and $2.71(\mathrm{t}, J=7.6 \mathrm{~Hz}, 2 \mathrm{H}) .{ }^{13} \mathrm{C} \mathrm{NMR}$ (126 MHz, DMSO, ppm) $\delta 170.80,152.92$ (2C), 143.14, 137.47, 136.15, 135.00, 132.44, 130.85 (2C), 130.52 (2C), 128.76, 127.88, 127.78, 124.66, 115.53, 106.94 (2C), 60.48, 56.40 (2C), 53.56, 30.34 and 24.84. MS (m/z) calculated for $\mathrm{C}_{25} \mathrm{H}_{27} \mathrm{ClN}_{2} \mathrm{O}_{6} \mathrm{~S}^{+}[\mathrm{M}+\mathrm{H}]^{+}: 517.12$, found: 517.16 .

4.4.5. N-(4-methylbenzyl)-2-oxo-N-(3,4,5-trimethoxyphenyl)-1,2,3,4-tetrahydroquinoline6-sulfonamide (D5)

White powder; yield 65\%; m.p. $128-130{ }^{\circ} \mathrm{C} .{ }^{1} \mathrm{H}$ NMR $\left(300 \mathrm{MHz}, \mathrm{CDCl}_{3}, \mathrm{ppm}\right) \delta 8.91$ $(\mathrm{s}, 1 \mathrm{H}), 7.56(\mathrm{dd}, J=12.5,4.2 \mathrm{~Hz}, 2 \mathrm{H}), 7.10(\mathrm{dd}, J=18.2,8.1 \mathrm{~Hz}, 4 \mathrm{H}), 6.97(\mathrm{~d}, J=8.3 \mathrm{~Hz}, 1 \mathrm{H})$, $6.17(\mathrm{~s}, 2 \mathrm{H}), 4.64(\mathrm{~s}, 2 \mathrm{H}), 3.81(\mathrm{~s}, 3 \mathrm{H}), 3.66(\mathrm{~s}, 6 \mathrm{H}), 3.01(\mathrm{t}, J=7.5 \mathrm{~Hz}, 2 \mathrm{H}), 2.69(\mathrm{t}, J=7.6 \mathrm{~Hz}$, $2 \mathrm{H})$ and $2.31(\mathrm{~s}, 3 \mathrm{H}) .{ }^{13} \mathrm{C} \mathrm{NMR}(126 \mathrm{MHz}, \mathrm{DMSO}, \mathrm{ppm}) \delta 170.82,153.01$ (2C), 143.60, $137.72,137.23,134.94,134.35,130.75,130.53,130.27,128.02,127.95,127.86,126.00,124.61$, $115.51,107.63(2 \mathrm{C}), 60.70,56.83(2 \mathrm{C}), 56.21,31.76,24.87$ and 19.22. MS ( $\mathrm{m} / \mathrm{z})$ calculated for $\mathrm{C}_{26} \mathrm{H}_{29} \mathrm{~N}_{2} \mathrm{O}_{6} \mathrm{~S}^{+}[\mathrm{M}+\mathrm{H}]^{+}:$497.17, found: 497.17 .

4.4.6. N-(4-(dimethylamino)benzyl)-2-oxo-N-(3,4,5-trimethoxyphenyl)-1,2,3,4tetrahydroquinoline-6-sulfonamide (D6)

White powder; yield 63\%; m.p. $127-129{ }^{\circ} \mathrm{C} .{ }^{1} \mathrm{H}$ NMR $\left(300 \mathrm{MHz}, \mathrm{CDCl}_{3}\right) \delta 8.20$ (s, $1 \mathrm{H}), 7.64-7.51(\mathrm{~m}, 2 \mathrm{H}), 7.07(\mathrm{~d}, J=8.5 \mathrm{~Hz}, 2 \mathrm{H}), 6.86(\mathrm{~d}, J=8.3 \mathrm{~Hz}, 1 \mathrm{H}), 6.60(\mathrm{~d}, J=8.7 \mathrm{~Hz}$, $2 \mathrm{H}), 6.17(\mathrm{~s}, 2 \mathrm{H}), 4.60(\mathrm{~s}, 2 \mathrm{H}), 3.82(\mathrm{~s}, 3 \mathrm{H}), 3.66(\mathrm{~s}, 6 \mathrm{H}), 3.02(\mathrm{t}, J=7.4 \mathrm{~Hz}, 2 \mathrm{H}), 2.92(\mathrm{~s}, 6 \mathrm{H})$ and 2.76-2.65 (m, 2H). ${ }^{13} \mathrm{C}$ NMR (126 MHz, DMSO, ppm) $\delta 170.82,152.79$ (2C), 150.20, 142.93 , 137.28, 135.13, 131.31, 129.75, 127.79, 127.71, 124.60, 123.74, 115.45, 112.48, 107.01, $60.47,56.35,53.93,30.35$ and 24.85. MS $(m / z)$ calculated for $\mathrm{C}_{27} \mathrm{H}_{32} \mathrm{~N}_{3} \mathrm{O}_{6} \mathrm{~S}^{+}[\mathrm{M}+\mathrm{H}]^{+}: 526.20$, found: 526.22 . 
4.4.7. N-(3-methylbenzyl)-2-oxo-N-(3,4,5-trimethoxyphenyl)-1,2,3,4-tetrahydroquinoline6-sulfonamide (D7)

White powder; yield 67\%; m.p. 120-122 ${ }^{\circ} \mathrm{C} .1 \mathrm{H} \mathrm{NMR}\left(300 \mathrm{MHz}, \mathrm{CDCl}_{3}, \mathrm{ppm}\right) \delta 9.14$ $(\mathrm{s}, 1 \mathrm{H}), 7.57(\mathrm{dd}, J=10.9,2.6 \mathrm{~Hz}, 2 \mathrm{H}), 7.10(\mathrm{dt}, J=19.5,7.9 \mathrm{~Hz}, 4 \mathrm{H}), 6.94(\mathrm{~d}, J=8.2 \mathrm{~Hz}, 1 \mathrm{H})$, $6.18(\mathrm{~s}, 2 \mathrm{H}), 4.66(\mathrm{~s}, 2 \mathrm{H}), 3.81(\mathrm{~s}, 3 \mathrm{H}), 3.66(\mathrm{~s}, 6 \mathrm{H}), 3.03(\mathrm{t}, J=7.5 \mathrm{~Hz}, 2 \mathrm{H}), 2.71(\mathrm{t}, J=7.6$ $\mathrm{Hz}, 2 \mathrm{H})$ and 2.30 (s, 3H). ${ }^{13} \mathrm{C}$ NMR (126 MHz, DMSO, ppm) $\delta 170.82,152.79$ (2C), 143.08, 137.48, 137.23, 134.94, 134.35, 130.75, 130.53, 130.27, 128.02, 127.95, 127.86, 126.00, 124.61, $115.51,107.00(2 \mathrm{C}), 60.50,56.36,52.64,45.91,30.36,24.87$ and 19.22. MS ( $\mathrm{m} / \mathrm{z})$ calculated for $\mathrm{C}_{26} \mathrm{H}_{29} \mathrm{~N}_{2} \mathrm{O}_{6} \mathrm{~S}^{+}[\mathrm{M}+\mathrm{H}]^{+}$: 497.17 , found: 497.18 .

4.4.8. N-(2-fluorobenzyl)-2-oxo-N-(3,4,5-trimethoxyphenyl)-1,2,3,4-tetrahydroquinoline6-sulfonamide (D8)

White powder; yield 56\%; m.p. $138-140{ }^{\circ} \mathrm{C} .{ }^{1} \mathrm{H}$ NMR $\left(300 \mathrm{MHz}, \mathrm{CDCl}_{3}, \mathrm{ppm}\right) \delta 8.90$ $(\mathrm{s}, 1 \mathrm{H}), 7.56(\mathrm{~d}, J=9.2 \mathrm{~Hz}, 2 \mathrm{H}), 7.27-7.19(\mathrm{~m}, 1 \mathrm{H}), 7.12-6.86(\mathrm{~m}, 4 \mathrm{H}), 6.19(\mathrm{~s}, 2 \mathrm{H}), 4.69$ (s, 2H), $3.82(\mathrm{~s}, 3 \mathrm{H}), 3.68(\mathrm{~s}, 6 \mathrm{H}), 3.03(\mathrm{t}, J=7.5 \mathrm{~Hz}, 2 \mathrm{H})$ and $2.71(\mathrm{t}, J=7.5 \mathrm{~Hz}, 2 \mathrm{H}) .{ }^{13} \mathrm{C} \mathrm{NMR}$ (75 $\left.\mathrm{MHz}_{2} \mathrm{CDCl}_{3}, \mathrm{ppm}\right) \delta 170.88,16.85,152.74(2 \mathrm{C}), 142.30,137.56,135.96,134.54,131.75$, 128.49 (2C), 128.25 (2C), 127.59, 127.41, 123.63, 115.46, 106.53 (2C), 60.65, 55.95 (2C), 55.07, 30.23 and 25.10. MS (m/z) calculated for $\mathrm{C}_{25} \mathrm{H}_{26} \mathrm{FN}_{2} \mathrm{O}_{6} \mathrm{~S}^{+}[\mathrm{M}+\mathrm{H}]^{+}: 501.15$, found: 501.18.

4.4.9. N-(2-chlorobenzyl)-2-oxo-N-(3,4,5-trimethoxyphenyl)-1,2,3,4-tetrahydroquinoline6-sulfonamide (D9)

White powder; yield 54\%; m.p. $117-119^{\circ} \mathrm{C} .{ }^{1} \mathrm{H}$ NMR $\left(300 \mathrm{MHz}, \mathrm{CDCl}_{3}, \mathrm{ppm}\right) \delta 8.64$ $(\mathrm{s}, 1 \mathrm{H}), 7.58-7.53(\mathrm{~m}, 2 \mathrm{H}), 7.28-7.17(\mathrm{~m}, 4 \mathrm{H}), 6.90(\mathrm{~d}, J=8.2 \mathrm{~Hz}, 1 \mathrm{H}), 6.17(\mathrm{~s}, 2 \mathrm{H}), 4.66$ $(\mathrm{s}, 2 \mathrm{H}), 3.82(\mathrm{~s}, 3 \mathrm{H}), 3.67(\mathrm{~s}, 6 \mathrm{H}), 3.03(\mathrm{t}, J=7.5 \mathrm{~Hz}, 2 \mathrm{H})$ and $2.71(\mathrm{t}, J=7.6 \mathrm{~Hz}, 2 \mathrm{H}) .{ }^{13} \mathrm{C}$ NMR (126 MHz, DMSO, ppm) $\delta 170.83,152.90$ (2C), 143.16, 137.59, 135.05, 134.19, 133.21, $131.50,130.73,129.81,129.76,127.96,127.85,127.62,124.66,115.51,107.00$ (2C), 60.51, 56.38 (2C), 52.21, 30.33 and 24.84. MS $(\mathrm{m} / z)$ calculated for $\mathrm{C}_{25} \mathrm{H}_{26} \mathrm{ClN}_{2} \mathrm{O}_{6} \mathrm{~S}^{+}[\mathrm{M}+\mathrm{H}]^{+}: 517.12$, found: 517.15 .

4.4.10. N-(3,4-dichlorobenzyl)-2-oxo-N-(3,4,5-trimethoxyphenyl)-1,2,3,4tetrahydroquinoline-6-sulfonamide (D10)

White powder; yield 64\%; m.p. $123-125{ }^{\circ} \mathrm{C} .{ }^{1} \mathrm{H}$ NMR (300 MHz, $\left.\mathrm{CDCl}_{3}, \mathrm{ppm}\right) \delta 8.57$ $(\mathrm{s}, 1 \mathrm{H}), 7.54(\mathrm{~d}, J=11.2 \mathrm{~Hz}, 2 \mathrm{H}), 7.37(\mathrm{~d}, J=7.7 \mathrm{~Hz}, 2 \mathrm{H}), 7.14(\mathrm{~d}, J=8.0 \mathrm{~Hz}, 1 \mathrm{H}), 6.90$ $(\mathrm{d}, J=8.1 \mathrm{~Hz}, 1 \mathrm{H}), 6.19(\mathrm{~s}, 2 \mathrm{H}), 4.64(\mathrm{~s}, 2 \mathrm{H}), 3.83(\mathrm{~s}, 3 \mathrm{H}), 3.70(\mathrm{~s}, 6 \mathrm{H}), 3.03(\mathrm{t}, J=7.4 \mathrm{~Hz}$, $2 \mathrm{H})$ and $2.71(\mathrm{t}, J=7.6 \mathrm{~Hz}, 2 \mathrm{H}) .{ }^{13} \mathrm{C} \mathrm{NMR}(126 \mathrm{MHz}, \mathrm{DMSO}, \mathrm{ppm}) \delta 170.81,152.99$ (2C), $143.22,138.46,137.55,134.95,131.31,131.04,130.63,130.53,130.43,128.94,127.95,127.82$, $124.69,115.54,106.92(2 \mathrm{C}), 60.49,56.43(2 \mathrm{C}), 53.07,30.32$ and 24.84 . MS ( $\mathrm{m} / \mathrm{z})$ calculated for $\mathrm{C}_{25} \mathrm{H}_{25} \mathrm{Cl}_{2} \mathrm{~N}_{2} \mathrm{O}_{6} \mathrm{~S}^{+}[\mathrm{M}+\mathrm{H}]^{+}:$551.08, found: 551.09 .

4.4.11. N-(5-chloro-2-fluorobenzyl)-2-oxo-N-(3,4,5-trimethoxyphenyl)-1,2,3,4tetrahydroquinoline-8-sulfonamide (D11)

White powder; yield 67\%; m.p. $124-126{ }^{\circ} \mathrm{C} .{ }^{1} \mathrm{H}$ NMR $\left(300 \mathrm{MHz}, \mathrm{CDCl}_{3}\right) \delta 8.86$ (s, $1 \mathrm{H}), 7.69-7.54(\mathrm{~m}, 2 \mathrm{H}), 7.14(\mathrm{dt}, J=12.5,7.9 \mathrm{~Hz}, 2 \mathrm{H}), 6.99-6.79(\mathrm{~m}, 2 \mathrm{H}), 6.21(\mathrm{~s}, 2 \mathrm{H}), 4.89$ $(\mathrm{s}, 2 \mathrm{H}), 3.80(\mathrm{~s}, 3 \mathrm{H}), 3.66(\mathrm{~s}, 6 \mathrm{H}), 3.04(\mathrm{t}, J=7.5 \mathrm{~Hz}, 2 \mathrm{H})$ and $2.71(\mathrm{t}, J=7.5 \mathrm{~Hz}, 2 \mathrm{H}) .{ }^{13} \mathrm{C}$ NMR (126 MHz, DMSO, ppm) $\delta$ 170.83, 160.87, 152.67 (2C), 143.21, 137.78, 134.58, 130.43, 128.04, 127.95, 126.03, 124.63, 121.95, 121.81, 115.46, 114.96, 114.78, 107.01 (2C), 60.55, 56.22 (2C), 46.42, 30.34 and 24.85. MS $(m / z)$ calculated for $\mathrm{C}_{25} \mathrm{H}_{25} \mathrm{ClFN}_{2} \mathrm{O}_{6} \mathrm{~S}^{+}[\mathrm{M}+\mathrm{H}]^{+}: 535.11$, found: 535.14 .

4.4.12. N-(3-methoxybenzyl)-2-oxo-N-(3,4,5-trimethoxyphenyl)-1,2,3,4tetrahydroquinoline-6-sulfonamide (D12)

White powder; yield 45\%; m.p. $121-123{ }^{\circ} \mathrm{C} .{ }^{1} \mathrm{H}$ NMR $\left(300 \mathrm{MHz}, \mathrm{CDCl}_{3}, \mathrm{ppm}\right) \delta 8.63$ $(\mathrm{s}, 1 \mathrm{H}), 7.59-7.52(\mathrm{~m}, 2 \mathrm{H}), 7.18(\mathrm{t}, J=8.1 \mathrm{~Hz}, 1 \mathrm{H}), 6.92(\mathrm{~d}, J=8.2 \mathrm{~Hz}, 1 \mathrm{H}), 6.84-6.77(\mathrm{~m}, 3 \mathrm{H})$, 
$6.20(\mathrm{~s}, 2 \mathrm{H}), 4.67(\mathrm{~s}, 2 \mathrm{H}), 3.82(\mathrm{~s}, 3 \mathrm{H}), 3.77(\mathrm{~s}, 3 \mathrm{H}), 3.67(\mathrm{~s}, 6 \mathrm{H}), 3.03(\mathrm{t}, J=7.5 \mathrm{~Hz}, 2 \mathrm{H})$ and $2.70(\mathrm{t}, J=9.0 \mathrm{~Hz}, 2 \mathrm{H}) .{ }^{13} \mathrm{C}$ NMR $(126 \mathrm{MHz}, \mathrm{DMSO}, \mathrm{ppm}) \delta 170.80,159.61,152.87$ (2C), 143.09 , 138.59, 137.40, 135.15, 131.00, 129.83, 127.86, 127.76, 124.65, 120.83, 115.52, 114.09, $113.34,106.93(2 \mathrm{C}), 60.47,56.38,55.42,54.14,45.86,30.34$ and 24.85. MS ( $\mathrm{m} / \mathrm{z})$ calculated for $\mathrm{C}_{26} \mathrm{H}_{29} \mathrm{~N}_{2} \mathrm{O}_{7} \mathrm{~S}^{+}[\mathrm{M}+\mathrm{H}]^{+}:$513.17, found: 513.19 .

4.4.13. N-(4-methoxybenzyl)-2-oxo-N-(3,4,5-trimethoxyphenyl)-1,2,3,4tetrahydroquinoline-6-sulfonamide (D13)

White powder; yield $48 \%$; m.p. $122-124{ }^{\circ} \mathrm{C} .{ }^{1} \mathrm{H}$ NMR $\left(300 \mathrm{MHz}, \mathrm{CDCl}_{3}, \mathrm{ppm}\right) \delta 8.36$ $(\mathrm{s}, 1 \mathrm{H}), 7.59-7.53(\mathrm{~m}, 2 \mathrm{H}), 7.15(\mathrm{~d}, J=8.6 \mathrm{~Hz}, 2 \mathrm{H}), 6.88(\mathrm{~d}, J=8.2 \mathrm{~Hz}, 1 \mathrm{H}), 6.80(\mathrm{~d}, J=8.7 \mathrm{~Hz}$, $2 \mathrm{H}), 6.16(\mathrm{~s}, 2 \mathrm{H}), 4.63(\mathrm{~s}, 2 \mathrm{H}), 3.82(\mathrm{~s}, 3 \mathrm{H}), 3.78(\mathrm{~s}, 3 \mathrm{H}), 3.66(\mathrm{~s}, 6 \mathrm{H}), 3.03(\mathrm{t}, J=7.5 \mathrm{~Hz}, 2 \mathrm{H})$ and $2.70(\mathrm{t}, J=9.0 \mathrm{~Hz}, 2 \mathrm{H}) .{ }^{13} \mathrm{C}$ NMR $(126 \mathrm{MHz}, \mathrm{DMSO}, \mathrm{ppm}) \delta 170.80,159.61,152.87(2 \mathrm{C})$, 143.09 , 138.59, 137.40, 135.15, 131.00, 129.83, 127.86, 127.76, 124.65, 120.83, 115.52, 114.09, $113.34,106.93(2 \mathrm{C}), 60.47,56.38,55.42,54.14,45.86,30.34$ and 24.85 . MS ( $\mathrm{m} / \mathrm{z})$ calculated for $\mathrm{C}_{26} \mathrm{H}_{29} \mathrm{~N}_{2} \mathrm{O}_{7} \mathrm{~S}^{+}[\mathrm{M}+\mathrm{H}]^{+}:$513.17, found: 513.19 .

4.4.14. N-(3,4-dimethoxybenzyl)-2-oxo-N-(3,4,5-trimethoxyphenyl)-1,2,3,4tetrahydroquinoline-6-sulfonamide (D14)

White powder; yield 49\%; m.p. $116-118^{\circ} \mathrm{C} .{ }^{1} \mathrm{H}$ NMR $\left(300 \mathrm{MHz}, \mathrm{CDCl}_{3}, \mathrm{ppm}\right) \delta 8.24$ $(\mathrm{s}, 1 \mathrm{H}), 7.62-7.52(\mathrm{~m}, 2 \mathrm{H}), 6.89(\mathrm{~d}, J=8.1 \mathrm{~Hz}, 1 \mathrm{H}), 6.86(\mathrm{~d}, J=1.8 \mathrm{~Hz}, 1 \mathrm{H}), 6.75-6.65(\mathrm{~m}, 2 \mathrm{H})$, $6.17(\mathrm{~s}, 2 \mathrm{H}), 4.63(\mathrm{~s}, 2 \mathrm{H}), 3.85(\mathrm{~s}, 3 \mathrm{H}), 3.84(\mathrm{~s}, 3 \mathrm{H}), 3.82(\mathrm{~s}, 3 \mathrm{H}), 3.67(\mathrm{~s}, 6 \mathrm{H}), 3.03(\mathrm{t}, J=7.5 \mathrm{~Hz}$, $2 \mathrm{H})$ and 2.75-2.66 (m, 2H). ${ }^{13} \mathrm{C}$ NMR (126 MHz, DMSO, ppm) $\delta 170.81,152.84(2 \mathrm{C}), 148.92$, $148.54,143.04,137.36,135.08,131.08,128.95,127.87,127.76,124.62,121.18,115.52,112.28$, 111.86, $107.03(2 \mathrm{C}), 60.47,56.38(2 \mathrm{C}), 55.82,53.97,45.88,30.34$ and 24.85 . MS ( $\mathrm{m} / \mathrm{z})$ calculated for $\mathrm{C}_{27} \mathrm{H}_{31} \mathrm{~N}_{2} \mathrm{O}_{8} \mathrm{~S}^{+}[\mathrm{M}+\mathrm{H}]^{+}$: 543.18, found: 543.15 .

4.4.15. O-(2,5-dimethoxybenzyl)-2-oxo-N-(3,4,5-trimethoxyphenyl)-1,2,3,4tetrahydroquinoline-6-sulfonamide (D15)

White powder; yield 62\%; m.p. $127-129^{\circ} \mathrm{C} .{ }^{1} \mathrm{H}$ NMR $\left(300 \mathrm{MHz}, \mathrm{CDCl}_{3}, \mathrm{ppm}\right) \delta 8.42$ $(\mathrm{s}, 1 \mathrm{H}), 7.62-7.50(\mathrm{~m}, 2 \mathrm{H}), 7.04(\mathrm{~d}, J=2.6 \mathrm{~Hz}, 1 \mathrm{H}), 6.88(\mathrm{~d}, J=8.3 \mathrm{~Hz}, 1 \mathrm{H}), 6.76-6.67(\mathrm{~m}$, $2 \mathrm{H}), 6.30(\mathrm{~s}, 2 \mathrm{H}), 4.74(\mathrm{~s}, 2 \mathrm{H}), 3.81(\mathrm{~s}, 3 \mathrm{H}), 3.76(\mathrm{~s}, 3 \mathrm{H}), 3.69(\mathrm{~s}, 6 \mathrm{H}), 3.63(\mathrm{~s}, 3 \mathrm{H}), 3.03(\mathrm{t}$, $J=7.6 \mathrm{~Hz}, 2 \mathrm{H})$ and $2.70(\mathrm{t}, J=7.5 \mathrm{~Hz}, 2 \mathrm{H}) .{ }^{13} \mathrm{C} \mathrm{NMR}(126 \mathrm{MHz}, \mathrm{DMSO}, \mathrm{ppm}) \delta 170.80$, 153.36, 152.84 (2C), 151.47, 143.07, 137.40, 135.55 (2C), 131.20, 127.84, 127.73, 125.70, 124.60, $115.80,115.49,113.65,112.34,106.89$ (2C), 60.50, 56.36, 56.26, 55.81, 49.42, 30.34 and 24.85. MS $(m / z)$ calculated for $\mathrm{C}_{27} \mathrm{H}_{31} \mathrm{~N}_{2} \mathrm{O}_{8} \mathrm{~S}^{+}[\mathrm{M}+\mathrm{H}]^{+}: 543.18$, found: 543.13 .

4.4.16. 2-oxo-N-(3,4,5-trimethoxybenzyl)-N-(3,4,5-trimethoxyphenyl)-1,2,3,4tetrahydroquinoline-6-sulfonamide (D16)

White powder; yield 62\%; m.p. $131-133{ }^{\circ} \mathrm{C} .{ }^{1} \mathrm{H}$ NMR (300 MHz, DMSO, ppm) $\delta 10.54$ $(\mathrm{s}, 1 \mathrm{H}), 7.51(\mathrm{~d}, J=6.1 \mathrm{~Hz}, 2 \mathrm{H}), 7.03(\mathrm{~d}, J=9.0 \mathrm{~Hz}, 1 \mathrm{H}), 6.54(\mathrm{~s}, 2 \mathrm{H}), 6.32(\mathrm{~s}, 2 \mathrm{H}), 4.65(\mathrm{~s}, 2 \mathrm{H})$, $3.68(\mathrm{~s}, 6 \mathrm{H}), 3.56(\mathrm{dd}, J=26.9,22.2 \mathrm{~Hz}, 12 \mathrm{H}), 3.02-2.90(\mathrm{~m}, 2 \mathrm{H})$ and $2.50(\mathrm{~s}, 2 \mathrm{H})$. MS $(\mathrm{m} / \mathrm{z})$ calculated for $\mathrm{C}_{28} \mathrm{H}_{33} \mathrm{~N}_{2} \mathrm{O}_{9} \mathrm{~S}^{+}[\mathrm{M}+\mathrm{H}]^{+}: 573.19$, found: 573.13 .

\subsection{In Vitro Anticancer Experiment}

The HeLa, HCT-116, A549 and HepG-2 cells in the logarithmic growth phase were trypsinized, diluted with 10\% DMEM medium and evenly seeded in a 96-well plate with $1 \times 10^{4}$ cells per well. We placed the inoculated 96-well plate in an incubator at $37^{\circ} \mathrm{C}$ and $5 \% \mathrm{CO}_{2}$ for $4 \mathrm{~h}$. After the cells adhered to the wall, we removed the medium. We added $150 \mu \mathrm{L}$ of medicated medium (1\% DMEM) to each well of the experimental group, and the control group was added with an equal volume of solvent, with 3 replicate holes for each concentration. Then, we put it in the incubator and continued to incubate for $48 \mathrm{~h}$. After that, we added MTT reagent in the dark, continued incubating for $4 \mathrm{~h}$, discarded the supernatant, added $150 \mu \mathrm{L}$ DMSO to each well and shook it for $10 \mathrm{~min}$ in the dark to fully 
dissolved the formazan. The absorbance was read at $492 \mathrm{~nm}$ by a microplate reader (ELx 800, BioTek, Highland Park, Winooski, VT, USA).

The inhibition rate $(\%)=(1$-dosing hole OD value/control hole OD value); we drew a logarithmic curve diagram according to the inhibition rate and the dosing concentration to obtain the half inhibitory concentration.

\subsection{In Vitro Tubulin Polymerization Assay}

A tubulin polymerization assay was performed by measuring the increase in the fluorescence intensity, which can be easily recorded due to the incorporation of a fluorescent reporter, DAPI (4',6-diamidino-2-phenylindole), a fluorophore that is known to be a DNA intercalator. In our experiment, a commercial kit (cytoskeleton, cat. \#BK011P) purchased from Cytoskeleton (Danvers, MA, USA) was used for the tubulin polymerization. The final buffer used for tubulin polymerization contained $80.0 \mathrm{mM}$ of piperazine- $\mathrm{N}_{,} \mathrm{N}^{\prime}-$ bis(2ethanesulfonic acid) sequisodium salt ( $\mathrm{pH} 6.9$ ), $2.0 \mathrm{mM} \mathrm{MgCl}_{2}, 0.5 \mathrm{mM}$ EGTA, $1.0 \mathrm{mM}$ GTP, and $10.2 \%$ of glycerol. First, $5 \mu \mathrm{L}$ of the tested compounds at the indicated concentrations was added, and the mixture was warmed to $37^{\circ} \mathrm{C}$ for $1 \mathrm{~min}$; then, the reaction was initiated by the addition of $55 \mathrm{uL}$ of the tubulin solution. The fluorescence intensity enhancement was recorded every $30 \mathrm{~s}$ for $40 \mathrm{~min}$ in a multifunction microplate reader (Molecular Devices, Flex Station 3) (emission wavelength of $420 \mathrm{~nm}$, excitation wavelength of $360 \mathrm{~nm}$ ). The area under the curve was used to determine the concentration that inhibited the tubulin polymerization by $50 \%\left(\mathrm{IC}_{50}\right)$, and was calculated using GraphPad Prism Software version5.02 (GraphPad Inc., La Jolla, CA, USA).

\subsection{Molecular Modeling}

Molecular docking was performed using the Discovery Studio (DS) 2017 Software. The protein and ligand samples were prepared, water molecules were deleted and a DS Server added hydrogen (https:/ / www.rcsb.org/structure/3HKC, accessed on 15 October 2021). The docking process was performed according to the CDOCKER protocol, where the technical parameter Pose Cluster Radius was reset to 0.5 and the other parameters were unchanged. The docking of the active site was set to the coordinates $x=39.42, y=52.17$ and $\mathrm{z}=-9.19$ as the center, with a radius of $7.43 \AA$ A spheres. The docking result was treated with DS Client.

Supplementary Materials: Figures S1-S16: 1H and 13C NMR data ( $\delta)$ for compounds 1-16.

Author Contributions: Conceptualization, J.M. and G.-H.G.; methodology, J.M. and G.-H.G.; investigation, J.M. and G.-H.G.; resources, G.-H.G.; writing-original draft preparation, J.M.; writingreview and editing, J.M. and G.-H.G.; visualization, J.M. and G.-H.G.; supervision, J.M. and G.-H.G.; project administration, J.M. and G.-H.G. All authors have read and agreed to the published version of the manuscript.

Funding: This research was funded by the Medical Science and Technology Research Accumulation Fund Project of Guangdong Province (No. B2021430).

Data Availability Statement: All data generated or analyzed during this study are included in this article.

Conflicts of Interest: The authors declare no conflict of interest.

\section{References}

1. Lehotzky, A.; Tokesi, N.; Gonzalez-Alvarez, L.; Merino, V.; Bermejo, M.; Orosz, F.; Lau, P.; Kovacs, G.G.; Ovadi, J. Progress in the development of early diagnosis and a drug with unique pharmacology to improve cancer therapy. Philos. Trans. R. Soc. A Math. Phys. Eng. Sci. 2008, 366, 3599-3617. [CrossRef] [PubMed]

2. Aly, H.A. Cancer therapy and vaccination. J. Immunol. Methods 2012, 382, 1-23. [CrossRef] [PubMed]

3. Nogales, E. Structural insights into microtubule function. Annu. Rev. Biochem. 2000, 69, 277-302. [CrossRef] [PubMed]

4. Quasthoff, S.; Hartung, H.P. Chemotherapy-induced peripheral neuropathy. J. Neurol. 2002, 249, 9-17. [CrossRef]

5. Ems-McClung, S.C.; Walczak, C.E. Kinesin-13s in mitosis: Key players in the spatial and temporal organization of spindle microtubules. Semin. Cell Dev. Biol. 2010, 21, 276-282. [CrossRef] 
6. Wittmann, T.; Hyman, A.; Desai, A. The spindle: A dynamic assembly of microtubules and motors. Nat. Cell. Biol. 2001, 3, E28-E34. [CrossRef]

7. Horio, T.; Murata, T. The role of dynamic instability in microtubule organization. Front. Plant Sci. 2014, 5, 511. [CrossRef]

8. Pellegrini, F.; Budman, D.R. Review: Tubulin function, action of antitubulin drugs, and new drug development. Cancer Investig. 2005, 23, 264-273. [CrossRef]

9. Fletcher, D.A.; Mullins, R.D. Cell mechanics and the cytoskeleton. Nature 2010, 463, 485-492. [CrossRef]

10. Prota, A.E.; Bargsten, K.; Zurwerra, D.; Field, J.J.; Díaz, J.F.; Altmann, K.H.; Steinmetz, M.O. Molecular mechanism of action of microtubule-stabilizing anticancer agents. Science 2013, 339, 587-590. [CrossRef]

11. Dumontet, C.; Jordan, M.A. Microtubule-binding agents: A dynamic field of cancer therapeutics. Nat. Rev. Drug Discov. 2010, 9 790-803. [CrossRef]

12. Jordan, M.A.; Wilson, L. Microtubules as a target for anticancer drugs. Nat. Rev. Cancer 2004, 4, 253-265. [CrossRef]

13. Nitika, V.; Kapil, K. Microtubule targeting agents: A benchmark in cancer therapy. Curr. Drug Ther. 2013, 8, 189-196. [CrossRef]

14. Protaa, A.E.; Bargstena, K.; Diazb, J.F.; Marshc, M.; Cuevasd, C.; Linigere, M.; Neuhause, C.; Andreub, J.M.; Altmanne, K.-H.; Steinmetza, M.O. A new tubulin-binding site and pharmacophore for microtubule-destabilizing anticancer drugs. Proc. Natl. Acad. Sci. USA 2014, 111, 13817-13821. [CrossRef]

15. Yang, J.; Yu, Y.; Li, Y.; Yan, W.; Ye, H.; Niu, L.; Tang, M.; Wang, Z.; Yang, Z.; Pei, H.; et al. Cevipabulin-tubulin complex reveals a novel agent binding site on $\alpha$-tubulin with tubulin degradation effect. Sci. Adv. 2021, 7, eabg4168. [CrossRef]

16. Jordan, M. Mechanism of action of antitumor drugs that interact with mi-crotubules and tubulin Anti-Cancer Agents. Curr. Med. Chem. Anti-Cancer Agents 2002, 2, 1-17. [CrossRef]

17. Vindya, N.G.; Sharma, N.; Yadav, M.; Ethiraj, K.R. Tubulins-the target for anticancer therapy. Curr. Top. Med. Chem. 2015, 15, 73-82. [CrossRef]

18. Karki, R.; Mariani, M.; Andreoli, M.; He, S.; Scambia, G.; Shahabi, S.; Ferlini, C. ßIII-Tubulin: Biomarker of taxane resistance or drug target? Expert Opin.Ther. Targets 2013, 17, 461-472. [CrossRef]

19. Kaur, R.; Kaur, G.; Gill, R.K.; Soni, R.; Bariwal, J. Recent developments in tubulin polymerization inhibitors: An overview. Eur. J. Med. Chem. 2014, 87, 89-124. [CrossRef]

20. Liu, Y.M.; Chen, H.L.; Lee, H.Y.; Liou, J.P. Tubulin inhibitors: A patent review. Expert Opin. Ther. Pat. 2014, 24, 69-88. [CrossRef]

21. Meng, T.; Wang, W.; Zhang, Z.; Ma, L.; Zhang, Y.; Miao, Z.; Shen, J. Synthesis and biological evaluation of $6 H-$ pyrido[ $\left[2^{\prime}, 1^{\prime}: 2,3\right]$ imidazo[4,5-c]isoquinolin5(6H)-ones as antimitotic agents and inhibitors of tubulin polymerization. Bioorg. Med. Chem. 2014, 22, 848-855. [CrossRef] [PubMed]

22. Tokali, F.S.; Taslimi, P.; Usanmaz, H.; Karaman, M.; Sendil, K. Synthesis, characterization, biological activity and molecular docking studies of novel schiff bases derived from thiosemicarbazide: Biochemical and computational approach. J. Mol. Struct. 2021, 1231, 129666. [CrossRef]

23. Hijji, Y.; Benjamin, E.; Butcher, R. Crystal structure, spectral, thermal and experimental/computational investigation of Anthracenbenzo[d]thiazol-2-amine new Schiff base derivative. J. Mol. Struct. 2020, 1229, 129824. [CrossRef]

24. Tashima, T.; Murata, H.; Kodama, H. Design and synthesis of novel and highly-active pan-histone deacetylase (pan-HDAC) inhibitors. Bioorg. Med. Chem. 2014, 22, 3720-3731. [CrossRef] 